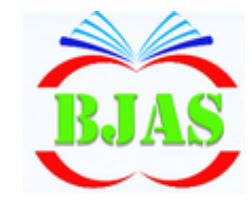

ISSN 1814 - 5868
Available online at http://bajas.edu.iq

https://doi.org/10.37077/25200860.2019.210 College of Agriculture, University of Basrah

Basrah J. Agric. Sci., 32(2): 208-212, 2019

\section{Basrah Journal of Agricultural Sciences}

E-ISSN: 2520-0860

\title{
Effect of Adding Lycium barbarum L. Extract to Drinking Water on Some Productive Traits of Japanese Quail (Coturnix japonica)
}

\author{
Arshad T.M. Sultan*, Khalid C.K. Al-Salhie \& Tarik F. Shawket
}

Department of Animal Production, College of Agriculture, University of Basrah, Basrah, Iraq

*Corresponding author e-mail: : *arshadtalip@gmail.com

Received 19 September 2019; Accepted 18 November 2019; Available online 31 December 2019

\begin{abstract}
This study was conducted to investigate the effect of adding Lycium barbarum extract to drinking water on some productive traits of Japanese quail. A total of 270 one-week-old Japanese quails were used in this study. The birds were divided into six treatments (45 for each). Each litre of drinking water (RO) was treated with $400 \mathrm{mg}$ of $L$. barbarum extract add from (leaves, fruits, stems, and roots) for T2, T3, T4, and T5 respectively. $400 \mathrm{mg}$ of mixed extract from leaves, stems, fruits and roots of L. barbarum were added to drinking water (T6). The control treatment (T1) was free of $L$. barbarum drinking water. The results showed no significant differences in the body weight, body weight gain, feed consumption and feed conversion ratio. A significant decrease in the age of sexual puberty and sexual maturity for males and females were recorded in the second and third treatments compared to the other treatments. On the other hand, the results showed no significant differences between the experimental treatments for the weight at sexual puberty and maturity for males and females. It can be concluded that the leaves and fruits of $L$. barbarum extract decreased the sexual puberty age for males and females of Japanese quail. On the other hand, it has no effect on body weight, body weight gain, feed consumption and feed conversion ratios.
\end{abstract}

Keywords: Lycium barbarum, Productive Traits, Quail.

\section{Introduction}

Lycium barbarum L., a member of the Solanaceae plants family, is a functional food (Zhang et al., 2013). In China, Tibet, and other Asian Nations, L. barbarum has been commonly grown and its commonly used as a plant and supplement in traditional Chinese medicine for more than 2000 years for the benefit of anti-aging, vision, kidney and liver function (Cheng et al., 2015). Recent studies have shown that extracts from $L$. barbarum are used to support these traditional characteristics. L. barbarum has a wide variety of biological activities, including effects on aging, neuroprotection, antifatigue/endurance, enhanced metabolism, glucose control in diabetics, glaucoma, antioxidant characteristics, immunomodulation, antitumor activity and cytoprotection (Potterat, 2010). Researchers are currently working to enhance the growth rate of livestock using helpful herbs (Banyapraphatsara, 2007). L. barbarum has been used in China for over 1000 years as herbal medicine to promote fertility (Luo et 
al., 2006). A little published data is concerning the use of $L$. barbarum, as a natural feed additive in poultry drinking water. This plant has been recorded for multiple activities such as antibacterial, antiinflammatory, anti-oxidant, blood sugar and cholesterol-reducing characteristics and immunomodulatory characteristics. The advantages of these medicinal plants are significant in animals health status (Javed et al., 2009). The aim at this study is to investigate the effect of adding $L$. barbarum extract from drinking water on some productive traits of Japanese quail.

\section{Material \& Methods}

This study was conducted at the Quail farm, College of Agriculture, University of Basrah for the period from 18 December 2018 to 25 January 2019. A total of 270 Japanese quail (Coturnix japonica) one week old with an average initial body weight of $27.96 \mathrm{~g}$ were used in this study. Chicks were randomly distributed to six treatments with three replicates each. Each litre of drinking water (RO) was supplemented with $400 \mathrm{mg}$ of $L$. barbarum extract of leaves, fruits, stems and root for T2, T3, T4, and $\mathrm{T} 5$ respectively, while T6 added $400 \mathrm{mg}$ of $L$. barbarum extract from the mixture of leaves, fruits, stems and roots (100 mg each) per litre of drinking water. First treatment (T1): the control group without any drinking water supplement. Chicks were housed in quail's cages under the same condition and rearing system. All chicks were kept under uniform management conditions throughout the experiment period. Chicks were fed approximately $24 \%$ crude protein; $2900 \mathrm{kcal} / \mathrm{kg}$ metabolizable energy until three weeks of age, after which they received commercial quail diet $20 \%$ crude protein; $2900 \mathrm{kcal} . \mathrm{kg}^{-1}$ metabolizable energy (NRC,
1994; Al-Salhie, \& Al- Waeli, 2019). Water and feed were ad libitum till the end of the study.

\section{Extract Preparation}

The plant parts include leaves, fruits, stems, and root washed carefully to remove dirt and dried under ambient temperature. The dried parts were ground by using laboratory blenders to a coarse powder form. $50 \mathrm{~g}$ of the powder was mixed into $250 \mathrm{ml}$ of ethanol in a clean glass beaker. The beaker was sealed and allow for $24 \mathrm{hrs}$ in a water bath $\left(37^{\circ} \mathrm{C}\right)$. After 24 hours, the mixture was mixed using magnetic stirrer for an hour. The mixture was filtered using a gauze. The filtrate was then spread to the centrifuge pipes at a velocity of $3000 \mathrm{rpm}$ for 15 minutes. Take the present, disregard the precipitate and position the glass of Petri dishes inside a $37^{\circ} \mathrm{C}$ drying oven. After drying, scrape the product and store it in the refrigerator for future use (Anessiny \& Perez, 1993).

\section{Study Parameters}

A quail body weight (BW) was recorded from the beginning to the end of the study (1-6 weeks of age). Body weight gains (BWG) was calculated as the changes in the body weight between 1-6 weeks of age. Feed consumption (FC) and feed conversion ratio (FCR) was calculated during 1-6 weeks of age. The age of sexual puberty for males was determined after confirming the production foam from the cloacal gland (Al-Salhie \& AlSwdani, 2013). The age of females sexual maturity is determined after egg production was reached 50\% (Quinn Jr et al., 2008; AlSalhie, 2012). Body weight at puberty and sexual maturity of both males and females were recorded by sensitive balance. 


\section{Statistical analysis}

All data were subjected to one-way variance analysis (ANOVA) and variations were deemed to be significant if $\mathrm{P}$ was $<0.05$ according to SPSS Statistics (SPSS, 2009).

\section{Results \& Discussion:}

The results in the table (1) showed no significant differences between the experimental treatments in body weight, body weight gain, feed consumption and feed conversion ratio. These findings were consistent with those of Nidaullah et al. (2010), they showed that the adding aqueous extract from different medicinal plants including L. barbarum at different levels of 3, 4, 6 and $10 \mathrm{~g} . \mathrm{l}^{-1}$ to drinking water of broilers did not significantly affect the body weight, feed consumption and feed conversion ratio.

Table (1): Effect of adding $L$. barbarum extracts to drinking water on some productive traits of Japanese quail at 1-6 weeks of age (Mean $\pm \mathrm{SE})$.

\begin{tabular}{|c|c|c|c|c|c|c|}
\hline \multicolumn{7}{|c|}{ Treatments } \\
\hline Parameters & $\mathrm{T} 1$ & $\mathrm{~T} 2$ & $\mathrm{~T} 3$ & $\mathrm{~T} 4$ & T5 & T6 \\
\hline $\begin{array}{l}\text { Final body } \\
\text { weight }(\mathrm{g})\end{array}$ & $\begin{array}{c}241.61 \\
\pm \\
6.14\end{array}$ & $\begin{array}{c}237.87 \\
\pm \\
4.95\end{array}$ & $\begin{array}{c}247.20 \\
\pm \\
3.52\end{array}$ & $\begin{array}{c}243.75 \\
\pm \\
3.26\end{array}$ & $\begin{array}{c}246.59 \\
\pm \\
5.49\end{array}$ & $\begin{array}{c}240.86 \\
\pm \\
5.22\end{array}$ \\
\hline $\begin{array}{l}\text { Bodyweight } \\
\text { gain }(\mathrm{g})\end{array}$ & $\begin{array}{c}213.65 \\
\pm \\
10.65\end{array}$ & $\begin{array}{c}209.91 \\
\pm \\
8.58\end{array}$ & $\begin{array}{c}219.24 \\
\pm \\
6.10\end{array}$ & $\begin{array}{c}215.79 \\
\pm \\
5.64\end{array}$ & $\begin{array}{c}218.63 \\
\pm \\
9.52\end{array}$ & $\begin{array}{c}212.91 \\
\pm \\
9.04\end{array}$ \\
\hline $\begin{array}{c}\text { Feed } \\
\text { consumption }(\mathrm{g})\end{array}$ & $\begin{array}{c}775.93 \\
\pm \\
12.82 \\
\end{array}$ & $\begin{array}{c}778.43 \\
\pm \\
29.31 \\
\end{array}$ & $\begin{array}{c}764.85 \\
\pm \\
28.12 \\
\end{array}$ & $\begin{array}{c}746.67 \\
\pm \\
14.57 \\
\end{array}$ & $\begin{array}{c}772.39 \\
\pm \\
33.54 \\
\end{array}$ & $\begin{array}{c}760.06 \\
\pm \\
31.83 \\
\end{array}$ \\
\hline $\begin{array}{l}\text { feed conversion } \\
\text { ratio }(\mathrm{g} / \mathrm{g})\end{array}$ & $\begin{array}{c}3.64 \\
\pm \\
0.24\end{array}$ & $\begin{array}{c}3.71 \\
\pm \\
0.28\end{array}$ & $\begin{array}{c}3.49 \\
\pm \\
0.08\end{array}$ & $\begin{array}{c}3.46 \\
\pm \\
0.02\end{array}$ & $\begin{array}{c}3.54 \\
\pm \\
0.31\end{array}$ & $\begin{array}{c}3.57 \\
\pm \\
0.21\end{array}$ \\
\hline
\end{tabular}

Table (2): Effect of adding $L$. barbarum extracts from drinking water on age and weight of sexual puberty for males and females (Mean \pm SE).

\begin{tabular}{|c|c|c|c|c|c|c|}
\hline \multicolumn{7}{|c|}{ Treatments } \\
\hline Parameters & $\mathrm{T} 1$ & $\mathrm{~T} 2$ & $\mathrm{~T} 3$ & $\mathrm{~T} 4$ & T5 & T6 \\
\hline $\begin{array}{l}\text { Age of sexual } \\
\text { puberty for } \\
\text { males (day) }\end{array}$ & $\begin{array}{c}32.88 \mathrm{a} \\
\pm \\
0.51 \\
\end{array}$ & $\begin{array}{c}31.22 \mathrm{~b} \\
\pm \\
0.36 \\
\end{array}$ & $\begin{array}{c}31.22 \mathrm{~b} \\
\pm \\
0.27 \\
\end{array}$ & $\begin{array}{c}32.22 \mathrm{ab} \\
\pm \\
0.22 \\
\end{array}$ & $\begin{array}{c}32.33 \mathrm{ab} \\
\pm \\
0.50 \\
\end{array}$ & $\begin{array}{c}33 \mathrm{a} \\
\pm \\
0.40 \\
\end{array}$ \\
\hline $\begin{array}{l}\text { The weight at } \\
\text { puberty sexual } \\
\text { of males (gm) }\end{array}$ & $\begin{array}{c}168.77 \\
\pm \\
2.59 \\
\end{array}$ & $\begin{array}{c}171.44 \\
\pm \\
4.52 \\
\end{array}$ & $\begin{array}{c}176.88 \\
\pm \\
5.01 \\
\end{array}$ & $\begin{array}{c}174.22 \\
\pm \\
4.85 \\
\end{array}$ & $\begin{array}{c}178.77 \\
\pm \\
8.08 \\
\end{array}$ & $\begin{array}{c}181.88 \\
\pm \\
4.78\end{array}$ \\
\hline $\begin{array}{l}\text { Age of sexual } \\
\text { maturity for } \\
\text { females (day) }\end{array}$ & $\begin{array}{c}42.66 \mathrm{a} \\
\pm \\
0.88\end{array}$ & $\begin{array}{c}39.66 \mathrm{~b} \\
\pm \\
0.34\end{array}$ & $\begin{array}{c}40 \mathrm{~b} \\
\pm \\
0.57\end{array}$ & $\begin{array}{c}42 \mathrm{a} \\
\pm \\
0.34\end{array}$ & $\begin{array}{c}42 \mathrm{a} \\
\pm \\
0.34\end{array}$ & $\begin{array}{c}42.67 \mathrm{a} \\
\pm \\
0.67\end{array}$ \\
\hline $\begin{array}{l}\text { The weight at } \\
\text { sexual maturity } \\
\text { of females (gm) }\end{array}$ & $\begin{array}{c}246.16 \\
\pm \\
11.37\end{array}$ & $\begin{array}{c}239.10 \\
\pm \\
1.18\end{array}$ & $\begin{array}{c}244.71 \\
\pm \\
2.99\end{array}$ & $\begin{array}{c}239.25 \\
\pm \\
6.18\end{array}$ & $\begin{array}{c}238.77 \\
\pm \\
5.34\end{array}$ & $\begin{array}{c}244.80 \\
\pm \\
7.33\end{array}$ \\
\hline
\end{tabular}

\footnotetext{
${ }^{\mathrm{a}, \mathrm{b}}$ Means in the same row with different letters show significant differences $(\mathrm{p}<0.05)$
} 
The results in the table (2) revealed significant differences $(P<0.05)$ among the studied treatments in the case of the age of sexual puberty and maturity of males and females. Quail males and females in the treatments (T2 and T3) recorded the lowest values compared to the control treatment (T1). These results may be due to the positive impacts on $L$. barbarum on sexual output and fertility. Also, the findings suggest that $L$. barbarum may be improve the copulatory performance and the reproductive function by mechanism: firstly, through regulation of the secretion of sexual hormones including the gonadotropin which promotes the hypophysis secretion of gonadal hormone and regulate the hypothalamic-pituitary-gonadal axis in a multiple manner. Secondly, L. barbarum may be increase the performance of spermatogenic cells through supporting the process of lipid peroxidation and other peroxide radicals on DNA, That lead to improve the sperm quantity, quality, improve fertility, decrease abnormalities of sperms, increase weight and coefficients of testes (Abdulrasool et al., 2014). These outcomes came in agreement with the finding of Zhang et al. (2013). L. barbarum which regulates the synthesis and the secretion of FSH and LH of the pituitary gonadotropic cells (Shi et al., 2017). These hormones play an active part in growing sexual cell activity and the sexual behaviour of birds and therefore early puberty (AlSalhie, 2018). The results of the present study showed no significant differences between the experimental treatments for the weight at sexual puberty and maturity for males and females of Japanese quail.

\section{Conclusions}

We can conclude that the leaves and fruits of L. barbarum extract decreased the age of sexual puberty for males and females of Japanese quail. On the other hand, it has no effect on body weight, body weight gain, feed consumption and feed conversion ratio.

\section{Acknowledgments}

The authors would like to express great appreciation for the Staff of Quail Farm, College of Agriculture, University of Basrah for the financial support this study.

Conflict of interest: The authors declare that they have no conflict of interest.

Ethical approval: all applicable national and international guidelines for the care and use of animals were followed.

\section{References}

Abdulrasool, A.A.; Fahmi, Z.M. \& Hasan, H.F. (2014). A comparative study on the fertility effects of phytochemical compounds isolated from the fruits of Euterpe Oleracea L. and Lycium barbarum L. with Tadalafil drug on male rats. Karbala J. Pharm. Sci.,(8): 98-109.

Al-Salhie, K.C.K. (2012). Effect of in ovo injection of testosterone and estrogen hormones and vitamin $\mathrm{C}$ on some reproductive, physiological, behavioral and productive traits of Japanese Quail (Coturnix japonica). Ph. D. Thesis. Coll. Agric., Univ. Basrah: 175pp.

Al-Salhie, K.C.K. (2018). The effect of age on growth and development of the gonads pre-to post sexual maturity of Japanese quail (Coturnix japonica). Kufa J. Agric. Sci., 10 (3): 39-55.

Al-Salhie, K.C.K \& Al-Swdani, S.M. (2013). Effect of egg weight on some productive and reproductive traits of Japanese quail under local situation. Basrah J. Agric. Sci., 26(1): 197-148.

Al-Salhie, K.C.K \& Al- Waeli, A.M. (2019). The effect of using different levels of red 
Sultan et al. / Basrah J. Agric. Sci., 32 (2): 218-222, 2019

ginseng roots powder on some physiological characteristics of Japanese Quail males (Coturnix japonica). Basrah J. Agric. Sci., 32(1): 34-38.

Anessiny, C. \& Perez, C. (1993). Screening of plants used in argentine folk medicine for anti-microbial activity. J. Ethnopharmacol., 39: 119-128.

Bunyapraphatsara, N. (2007). Utilization of medicinal plants in animal production. $11^{\text {th }}$ Int. Cong., Leiden, The Neth. Phytopharmacol.: 144.

Cheng, J.; Zhou, Z.-W.; Sheng, H.P.; He, L.J.; Fan, X.W.; He, Z.X.; Sun, T.; Zhang, X.; Zhao, R.J. \& Gu, L. (2015). An evidencebased update on the pharmacological activities and possible molecular targets of Lycium barbarum polysaccharides. J. Drug Des. Dev. Ther., 9: 33-78.

Javed, M.; Durrani, F.-R.; Hafeez, A.; Khan, R.U. \& Ahmad, I. (2009). Effect of aqueous extract of plant mixture on carcass quality of broiler chicks. Arpn J. Agric. Biol. Sci.,4 (1): 37-40.

Luo, Q.; Li, Z.; Huang, X.; Yan, J.; Zhang, S. \& Cai,Y.Z. (2006). Lycium barbarum polysaccharides: Protective effects against heat-induced damage of rat testes and $\mathrm{H} 2 \mathrm{O} 2$-induced DNA damage in mouse testicular cells and beneficial effect on sexual behavior and reproductive function of hemicastrated rats. J. Life Sci., 79(7): 613-621.

Nidaullah, H.; Durrani, F.; Ahmad, S.; Jan, I. \& Gul, S. (2010). Aqueous extract from different medicinal plants as anticoccidial, growth promotive and immunostimulant in broilers. J. Agric. Biol. Sci., 5(1): 53-59.

NRC, National Research Council. (1994). Nutrient Requirements of Poultry. $9^{\text {th }}$ Rev. Ed. National Academy Press. Washington, D.C. $176 \mathrm{pp}$.

Potterat, O. (2010). Goji (Lycium barbarum and L. chineense): phytochemistry, pharmacology, and safety in the perspective of traditional uses and recent popularity. J. Planta Med., 76(1): 7-19.

Quinn Jr, M.; Summitt, C.L. \& Ottinger, M. A. (2008). Consequences of in ovo exposure to $p, p^{\prime}$-DDE on reproductive development and function in Japanese quail. J. Horm. Behav., 1: 249-253.

Shi, G.J.; Zheng, J.; Wu, J.; Qiao, H.Q.; Chang, Q.; Niu, Y.; Sun, T.; Li, Y.X. \& Yu, J.Q. (2017). Protective effects of Lycium barbarum polysaccharide on male sexual dysfunction and fertility impairments by activating hypothalamicpituitary-gonadal axis in streptozotocininduced type-1 diabetic male mice. J. Endocr., 64 (9): 907-922.

SPSS, (2009). Statistical Packages of Social Sciences. Version 18.

Zhang, C.; Wang, A.; Sun, X.; Li, X.; Zhao, X.; Li, S. \& Ma, A. (2013). Protective Effects of Lycium barbarum polysaccharides on testis spermatogenic injury induced by bisphenol $\mathrm{A}$ in mice. $\mathrm{J}$. Evid.-Based Complem. Altern. Med, 2013,: 9pp.http://dx.doi.org/ 10.1155/2013/690808. 